\title{
STUDI KELOMPOK SIAMANG (Hylobates syndactylus) DI REPONG DAMAR PAHMUNGAN PESISIR BARAT
}

\section{(STUDY GROUPS OF SIAMANG (Hylobates syndactylus) IN REPONG DAMAR OF PAHMUNGAN WEST COAST)}

\author{
Erna Maya Sari ${ }^{1)}$ dan Sugeng P. Harianto ${ }^{2)}$ \\ ${ }^{1)}$ Mahasiswa Jurusan Kehutanan Fakultas Pertanian Universitas Lampung \\ ${ }^{2)}$ Dosen Pengajar dan Peneliti Jurusan Kehutanan Fakultas Pertanian Universitas Lampung \\ Jl. Soemantri Brojonegoro No. I Bandar Lampung \\ E-mail : mayasari.erna22@gmail.com \\ No. Telepon : 085669403046
}

\begin{abstract}
ABSTRAK
Repong Damar di Pekon Pahmungan, Kabupaten Pesisir Barat merupakan penyangga Taman Nasional Bukit Barisan Selatan (TNBBS). Repong Damar adalah salah satu contoh keberhasilan agroforestri yang dikelola oleh masyarakat lokal yang masih sangat tradisional. Areal ini teridentifikasi sebagai habitat siamang (Hylobates syndactylus). Belum adanya data dan informasi terbaru mengenai kelompok siamang di Pekon Pahmungan menyebabkan penelitian ini dilakukan. Penelitian ini bertujuan untuk mengetahui kelompok siamang di Repong Damar dengan menggunakan metode area terkonsentrasi. Penelitian dilakukan pada bulan April 2015. Hasil penelitian ini menunjukkan bahwa kelompok siamang yang dijumpai di Repong Damar Pahmungan berjumlah 4 individu/kelompok. Distribusi kelas umur pada individu fase dewasa berjumlah 2 individu dan fase remaja berjumlah 2 individu. Nilai rasio seksual pada kelas umur fase dewasa yaitu 1:1 dan pada kelas umur fase remaja 1:1.
\end{abstract}

Kata kunci: siamang, kelompok, repong damar

ABSTRACT

Repong Damar in Pahmungan, West Coastal District is a buffer of Bukit Barisan Selatan National Park (TNBBS). Repong Damar is one example of the success of agroforestry systems managed by local community that is still very traditional. This area was identified as a component of siamang (Hylobates syndactylus) habitat. The absence of data and the latest information about the siamang groups in Pekon Pahmungan were reasons of this research. The purpose of this research was to determine the siamang groups in Repong Damar, used concentrated area methode. The research was done on April 2015. The results showed that the existence of siamang group in Repong Damar Pahmungan were 4 individuals/group. The distribution of age classes in the individual phases of adult siamang were 2 individuals and the individual of adolescent phase were 2 individuals. The sex ratio in the adult age class phase was 1:1 and at adolescent age class phase was 1:1.

Keywords: siamang, groups, repong damar

\section{PENDAHULUAN}

Siamang (Hylobates syndactilus) merupakan primata dari famili Hylobatidae yang termasuk spesies terancam punah akibat degradasi hutan sebagai habitat alaminya dan perburuan untuk diperdagangkan. Penyebaran siamang terbatas di Pulau Sumatera dan beberapa wilayah Semenanjung Melayu, menempati hutan tropis dataran rendah dan hutan 
tropis pegunungan hingga ketinggian 2000 mdpl. Saat ini, populasi siamang yang tersisa di Sumatera sebagian besar hanya terdapat di kawasan lindung dan konservasi (Nijman dan Geissman, 2006). Siamang termasuk spesies yang dilindungi berdasarkan PP No. 7 Tahun 1999 serta termasuk dalam IUCN (International Union on Conservation for Nature) redlist endangered species dan CITES (Convention on International Trade in Endangered Species of Wild Fauna and Flora) appendix I. Kegiatan konservasi siamang melalui perlindungan terhadap spesies dan habitatnya sangat penting untuk dilakukan guna mencegah terjadinya kepunahan jenis satwa ini.

Areal Repong Damar yang berada di Pekon Pahmungan, Kabupaten Pesisir Barat merupakan penyangga Taman Nasional Bukit Barisan Selatan (TNBBS). Areal ini teridentifikasi sebagai komponen habitat siamang (Nainggolan, 2011). Empat jenis primata ditemukan di areal repong damar yaitu siamang (Hylobates syndactylus), monyet ekor panjang (Macaca fascicularis), cecah (Presbytis melalophos), dan lutung kelabu (Presbytis cristata). Siamang merupakan spesies primata yang ditemukan dengan jumlah terbesar kedua setelah monyet ekor panjang yaitu lebih kurang 21 ekor. Penelitian tentang studi kelompok siamang perlu dilakukan mengingat hingga saat ini belum banyak diketahuinya keberadaan kelompok siamang oleh masyarakat umum begitu juga data terbaru mengenai kelompok siamang di Repong Damar, Pekon Pahmungan.

Tujuan dari penelitian ini adalah untuk mengetahui ukuran kelompok siamang, susunan komposisi umur siamang, rasio seksual siamang dan kondisi habitat siamang di Repong Damar, Pekon Pahmungan, Kecamatan Pesisir Tengah, Kabupaten Pesisir Barat.

\section{METODE PENELITIAN}

Penelitian ini dilaksanakan pada bulan April 2015 di Repong Damar, Pekon Pahmungan, Kecamatan Pesisir Tengah, Kabupaten Pesisir Barat. Alat yang digunakan dalam penelitian ini adalah: GPS (Global Positioning System), kamera digital, binokular, jam tangan digital, alat tulis, laptop dan lembar data/kerja. Objek penelitian adalah siamang yang berada di areal Repong Damar, Pekon Pahmungan. Data yang dikumpulkan yaitu data primer mengenai kelompok siamang yang meliputi: ukuran kelompok siamang, komposisi umur siamang dan rasio seksual siamang dengan menggunakan metode terkonsentrasi (Concentration Count) (Bismark, 2009 dalam Setya, 2012) yaitu pengamatan dilaksanakan terkonsentrasi pada satu titik yang diduga memiliki intensitas penjumpaan terhadap satwa tinggi dan data sekunder meliputi data penunjang yang terkait dengan penelitian ini berupa kondisi umum lokasi penelitian, dan peta lokasi serta gambaran umum mengenai siamang yang diperoleh melalui studi literatur. Data primer diperoleh melalui survei pendahuluan untuk menetukan titik pengamatan, mengetahui kondisi umum lokasi penelitian dan menentukan jalur dan titik yang memiliki peluang tinggi ditemukannya siamang serta observasi langsung yang dilakukan pada bulan April selama 14 hari efektif dimulai dari pukul 06.00-18.00 WIB.

\section{HASIL DAN PEMBAHASAN}

\section{A. Repong Damar Pahmungan Sebagai Habitat Siamang}

Areal Repong Damar yang terletak di Pekon Pahmungan merupakan salah satu contoh pengelolaan lahan hutan yang perlu mendapat perhatian, sebab Repong Damar merupakan keberhasilan agroforestri yang dikelola oleh masyarakat lokal yang masih sangat tradisional. Repong Damar merupakan istilah yang digunakan masyarakat lokal dalam menyebut kebun damar. Repong Damar tidak hanya terdiri dari damar saja melainkan terdapat jenis tumbuhan lainnya seperti durian (Durio zibethinus), manggis (Garcinia mangostana), duku (Lansium 
domesticum), cempedak (Artocarpus champeden), semak belukar, kayu-kayuan, dan obatobatan (Herawati, 2012).

Kebun-kebun damar dapat dikategorikan sebagai hutan, karena memang secara biologi kebun-kebun tersebut adalah hutan itu sendiri, suatu komunitas tumbuhan dan binatang yang kompleks dan juga merupakan suatu proses-proses biologi yang selaras yang dapat berkembang biak dalam jangka panjang dengan dinamikanya sendiri (FKKM, 2002). Hal ini terlihat dari banyaknya satwa liar yang menjadikan areal ini sebagai habitat dan dapat berjalan selaras dengan keberadaan Repong Damar ini. Berbagai jenis satwa liar dapat hidup disini, seperti mamalia, unggas, reptil dan lain sebagainya.

Vegetasi adalah tempat hidup bagi primata karena seluruh aktivitasnya dilakukan diatas pohon. Primata umumnya memilih lokasi untuk mencari pakan pada bagian tengah dan bagian atas tajuk pohon (Suyanto, Sinaga, dan Saim, 2009). Vegetasi yang ada pada satu tempat merupakan salah satu faktor yang penting sebagai komponen habitat primata. Hampir semua jenis primata memilih pohon-pohon yang tinggi dan tajuknya lebat. Menurut Whitten (1980) dikutip oleh Bismark (2006), pemilihan pohon tinggi sebagai pohon tempat tidur bertujuan untuk mengurangi resiko primata terhadap predator. Iskandar (2007) dikutip oleh Bungun, Mansjoer dan Bismark (2009), menyatakan bahwa jenis pohon yang digunakan sebagai pohon tempat tidur primata adalah jenis pohon yang pada umumnya juga dimanfaatkan sebagai pohon sumber pakan.

Jenis-jenis tumbuhan yang ada di Repong Damar, Pekon Pahmungan cukup beragam mulai dari strata tajuk tinggi hingga strata tajuk rendah (Tabel 1). Sangat dimungkinkan untuk primata hidup didalamnya, khususnya siamang karena struktur dan komposisi vegetasi Repong Damar mendukung jenis primata melakukan aktivitas harian, tempat berlindung, dan tempat berkembangbiak. Saat pengamatan bertepatan dengan musim panen buah-buahan, diantaranya buah durian, manggis, cempedak dan duku sehingga persediaan pakan berlimpah.

Ketersediaan pakan sangat penting untuk kebutuhan dari beberapa jenis primata yang hidup didalamnya. Apabila habitat tidak lagi memenuhi kebutuhan hidup primata maka primata tersebut akan pindah ketempat lain. Keanekaragaman vegetasi yang tinggi, akan memiliki keanekaragaman hewan yang tinggi, karena setiap jenis hewan tergantung pada sekelompok vegetasi tertentu. Habitat primata dapat diukur dari beberapa parameter vegetasi yang berada di sekitar pohon tidur atau areal yang berpotensi atau tersedia pohon tempat tidur (Bismark, 2006).

Tabel 1. Jenis tumbuhan pada vegetasi di Repong Damar, Pekon Pahmungan, Kecamatan Pesisir Tengah, Kabupaten Lampung Barat.

\begin{tabular}{clll}
\hline No & Nama Nasional & Nama Ilmiah & Famili \\
\hline 1. & Durian & Durio zibethinus & Bombacaceae \\
2. & Jengkol & Pithecellobium lobatum & Mimosaceae \\
3. & Damar & Shorea javanica & Dipterocarpaceae \\
4. & Duku & Lansium domesticum & Meliaceae \\
5. & Petai & Parkia speciosa & Mimosaceae \\
6. & Manggis & Garcinia mangostana & Guttiferae \\
7. & Beringin & Ficus benjamina & Moraceae \\
8. & Cempedak & Artocarpus champeden & Moraceae \\
9. & Tupak & Bacacaurea dulcis & Euphorbiaceae \\
10. & Binjai & Mangifera caesia & Anacardiaceae \\
11. & Tangkil & Gnetum gnemon & Gnetaceae \\
\hline
\end{tabular}




\section{B. Kelompok Siamang di Repong Damar Pahmungan}

Areal Repong Damar di Pekon Pahmungan merupakan habitat bagi kehidupan satwa liar, salah satunya adalah siamang. Berdasarkan hasil penelitian, kelompok siamang yang ditemui pada lokasi pengamatan berjumlah 2-4 individu, kelompok siamang ditemukan pada 14 (empat belas) kali perjumpaan secara langsung di 3 lokasi pengamatan yang berbeda (Gambar 1).

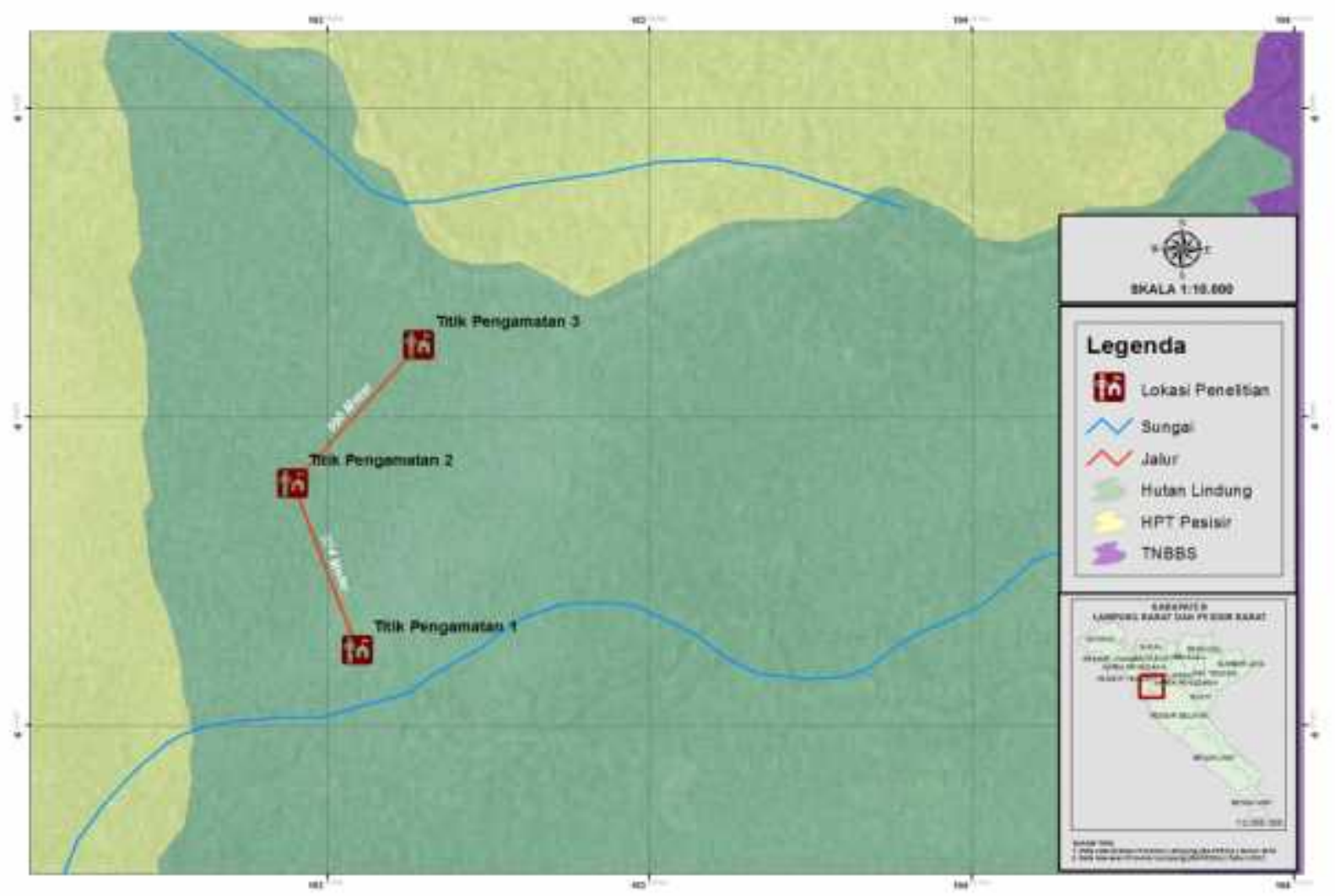

Gambar 1. Lokasi pengamatan siamang di Repong Damar, Pahmungan, Pesisir Barat.

Pada lokasi pengamatan pertama didapat 6 kali perjumpaan $(n=6)$. Kelompok terbesar siamang yang ditemui di lokasi pertama terdiri dari 1 individu jantan remaja, 1 individu jantan dewasa, 1 betina remaja dan 1 individu betina dewasa. Lokasi pengamatan pertama berada pada kebun milik masyarakat yang didominasi oleh pohon damar. Pohon damar ini dijadikan sebagai pohon tidur oleh siamang. Di lokasi ini juga ditemukan jenis satwa lain yaitu babi hutan, beruk, lutung kelabu, cecah, monyet ekor panjang, kukang, dan kijang (Tabel 2).

Pada lokasi pengamatan kedua didapat 2 kali perjumpaan $(n=2)$. Kelompok terbesar siamang yang ditemui di lokasi pengamatan kedua terdiri dari, 1 individu jantan dewasa, 1 individu betina dewasa, 1 individu remaja tidak teridentifikasi jenis kelaminnya. Kondisi vegetasi pada lokasi pengamatan kedua tidak jauh berbeda dengan kondisi pada lokasi pengamatan pertama, namun lokasi ini lebih didominasi oleh pohon duku dan manggis. Pohon duku ini dijadikan salah satu sumber pakan oleh siamang, jarak antara lokasi pengamatan pertama dan kedua adalah 574 meter (Gambar 1). Ditemukan juga jenis satwa lain yaitu babi hutan, beruk, monyet ekor panjang, cecah dan kukang (tabel 2).

Di lokasi pengamatan ketiga didapat 6 kali perjumpaan $(n=6)$. Kelompok terbesar siamang yang ditemui pada lokasi pengamatan ketiga terdiri dari, 1 individu jantan remaja, 1 individu jantan dewasa, 1 individu betina remaja dan 1 individu betina dewasa. Kondisi lokasi pengamatan ketiga berada pada kebun milik masyarakat namun vegetasinya lebih rapat dibandingkan dengan lokasi pengamatan pertama dan kedua. Lokasi ini lebih didominasi 
oleh tanaman duku, manggis dan tupak (Bacacaurea dulcis). Titik ini juga dijadikan salah satu sumber pakan oleh siamang. Jarak antara lokasi pengamatan kedua dan ketiga yaitu meter 595 meter (Gambar 1) dan lokasi ini juga ditemukan jenis satwa lain yang berada di sekitar lokasi pengamatan siamang disajikan pada (Tabel 2).

Pada 14 kali perjumpaan siamang di lokasi pengamatan, frekuensi perjumpaan yang tertinggi yaitu pada lokasi pengamatan pertama $(n=6)$ dan lokasi pengamatan ketiga $(n=6)$, sedangkan frekuensi perjumpaan yang terendah ditemukan pada lokasi pengamatan ketiga yaitu $(n=2)$. Ukuran kelompok siamang yang terbesar dari seluruh lokasi pengamatan berjumlah 4 individu yang terdiri dari 1 individu jantan remaja, 1 individu jantan dewasa, 1 individu betina remaja dan 1 individu betina dewasa dan ukuran kelompok terkecil dari seluruh lokasi pengamatan yaitu berjumlah 2 individu yang terdiri dari 1 individu jantan dewasa dan 1 individu betina dewasa. Komposisi kelompok siamang ditentukan berdasarkan fase pertumbuhan siamang (Gittins \& Raemaekers, 1980).

Komposisi serta struktur sosial siamang mempunyai keunikan yaitu membentuk kelompok inti berupa keluarga kecil sehingga berbeda dengan kerabat kera-kera lain. Siamang hidup dalam pasangan dengan jumlah anak sampai empat ekor dan setelah anak tersebut dewasa akan meninggalkan kelompok karena anggota kelompok yang lebih dewasa sangat galak terhadap yang muda dari jenis kelamin sama (Alikodra, 2002). Siamang bersifat monogami yaitu hanya terdapat satu pasang jantan dan betina dewasa ditambah satu sampai tiga individu muda dalam keluarga (Tenaza, 1975). Individu jenis yang sama akan memiliki kebutuhan hidup yang sama dengan cara mendapatkan relatif sama, sehingga dalam memenuhi kebutuhan tersebut satu individu memerlukan interaksi dengan individu lainnya. Interaksi tersebut akan berlanjut antar beberapa individu yang lebih banyak. Hubungan tersebut akan menghasilkan suatu aturan sosial dan membentuk struktur sosial dengan kebiasaan yang diterapkan dalam kelompok tersebut (McFarland, 1999). Individu siamang akan siap untuk 14 melakukan perkawinan pada umur 8-9 tahun. Masa kehamilan antara 7-8 bulan dengan jarak kelahiran antara 2-2,5 tahun. Masa hidup dapat mencapai 25 tahun (Supriatna dan Wahyono, 2002).

Besar kecilnya ukuran kelompok siamang dipengaruhi oleh kondisi lingkungan seperti kerapatan vegetasi, topografi, iklim atau cuaca, ketersediaan jumlah pakan dan keberadaan predator atau kompetitor. Hal ini didukung oleh Bismark (2009), yang menyatakan bahwa faktor yang mempengaruhi jumlah individu dalam kelompok adalah sumberdaya pakan dan lingkungan yang memungkinkan untuk memelihara anak dengan baik. Pada pengamatan siamang di lokasi penelitian, perjumpaan langsung dengan kelompok siamang terjadi pada 2 kondisi cuaca yang berbeda yaitu pada cuaca cerah $(n=11)$ dan cuaca setelah hujan $(n=3)$.

Berdasarkan fase pertumbuhan siamang, terdapat tiga kategori umur yang diidentifikasi, yaitu bayi, remaja, dan dewasa. Proporsi perjumpaan tiap kategori dalam hasil penelitian ini adalah $0 \%$ bayi, $38,10 \%$ remaja, dan $61,90 \%$ dewasa. Kelompok dewasa merupakan kategori umur dengan jumlah perjumpaan terbanyak dibandingkan kategori lainnya.

Perbandingan jantan dan betina (sex ratio) pada kategori dewasa yaitu (1:1) dan kategori remaja yaitu (1:1). Perbandingan antara jantan dan betina tersebut merupakan hal yang wajar dikarenakan siamang merupakan jenis kera yang bersifat monogami. Selama pengamatan ditemukan juga satu kelompok siamang lain. Kelompok siamang tersebut berjumlah 3 individu yang terdiri dari 1 jantan dewasa, 1 betina dewasa dan 1 jantan remaja.

Komposisi jenis kelamin merupakan suatu strategi reproduksi dari sistem perkawinan monogami, dimana rasio seksual 1:1 merupakan kondisi yang tepat untuk menjaga kestabilan populasi (Rinaldi, 1992). Dari hasil pengamatan dapat dilihat perbandingan individu jantan dengan betina adalah 1:1, keadaan ini menunjukkan kestabilan komposisi jenis kelamin yang nantinya dapat berpengaruh terhadap populasi ke depannya. Pada penelitian ini tidak 
ditemukan siamang dengan kategori umur bayi. Hal ini disebabkan siamang bereproduksi dengan jarak kelahiran 2-2,5 tahun dan jarak kehamilan antara 7-8 bulan.

\section{Aktivitas Harian Siamang di Repong Damar Pahmungan}

Aktivitas kelompok siamang di areal Repong Damar rata-rata dimulai dari pukul 06.30 WIB dan berakhir pukul 17.00 WIB. Aktivitas pertama yang biasa dilakukan oleh kelompok siamang ini adalah kegiatan bersuara. Aktivitas ini bertujuan untuk menunjukkan keberadaannya di habitat ini dan menyatakan hubungan sosial antar individu siamang. Aktivitas bersuara ini biasanya dilakukan saat matahari terbit, kelompok siamang masih di pohon tempat mereka tidur. Beberapa jenis pohon yang dijadikan sebagai pohon tidur oleh siamang di Repong Damar, Pekon Pahmungan adalah pohon damar (Shorea javanica) dan beringin (Ficus benjamina).

Aktivitas kelompok siamang di Repong Damar ini sangat dipengaruhi oleh cuaca, baik aktivitas bergerak, bersuara maupun makan. Ketika hujan siamang lebih memilih untuk berteduh di dahan pohon dengan ketinggian di atas 30 meter. Ketika pagi turun hujan maka suara siamang tidak terdengar sama sekali. Dari hasil penelitian, saat cuaca hujan, kelompok siamang biasanya akan bersuara ketika hujan reda dan matahari mulai muncul.

Jarak jelajah siamang juga sangat berpengaruh ketika sedang hujan. Siamang biasanya hanya bergerak di sekitar pohon-pohon dengan ketinggian lebih dari 30 meter dan dengan tajuk yang rapat. Kelompok siamang ini memiliki insting yang cukup tinggi terhadap cuaca. Ketika cuaca mulai mendung, biasanya kelompok siamang ini akan mempercepat aktivitasnya dan bergerak ke bagian hutan yang lebih aman ketika hari hujan, biasanya posisinya tidak jauh dari pohon tidurnya.

Siamang merupakan jenis kera pemakan buah, bunga dan pucuk-pucuk daun (Renaldi, 1992), namun berdasarkan penelitian yang telah dilakukan di areal Repong Damar Pahmungan siamang lebih sering memakan buah yang ada di areal tersebut. Hal ini dikarenakan pada saat penelitian dilakukan di lokasi tersebut sedang dalam fase musim buahbuahan. Areal Repong Damar Pahmungan memiliki 4 jenis tumbuhan yang buahnya dimakan oleh siamang yaitu buah duku, tupak, manggis dan cempedak. Walaupun siamang lebih banyak mengkonsumsi buah, sesekali kelompok siamang yang ada di areal Repong Damar juga memakan bunga dan pucuk-pucuk daun. Tanaman yang dimakan bunga dan pucukpucuk daunnya adalah petai (Parkia speciosa), jengkol (Pithecellobium lobatum), dan cempedak (Artocarpus champeden).

Kelompok siamang di Repong Damara berinteraksi dengan jenis kera lain yang ada di areal tersebut seperti beruk, cecah, dan monyet ekor panjang. Siamang termasuk hewan yang cukup toleran dengan bangsa kera lainnya. Siamang dapat hidup dalam satu areal yang sama dengan monyet ekor panjang, cecah, dan beruk. Sekalipun dalam aktivitas hariannya mereka hidup dalam areal yang sama, namun tidak saling jumpa karena berbeda secara vertikal maupun kebiasaannya (Harianto, 1988).

Menurut Harianto (1988), untuk kelangsungan hidupnya setiap binatang mempunyai tingkah laku sosial yang berbeda, baik terhadap individu di dalam kelompoknya atau terhadap spesies yang berlainan di luar kelompoknya. Tingkah laku sosial yang terjadi dalam kehidupan siamang dapat dikelompokkan menjadi 4 bagian, yaitu: antar individu-individu dalam kelompoknya, antar kelompok dengan kelompok siamang lainnya, antar kelompok siamang dengan jenis kera lainnya, dan antar kelompok siamang dengan satwa lainnya. Aktivitas atau interaksi sosial siamang yang terjadi di areal Repong Damar, Pekon Pahmungan yaitu antara individu-individu dalam kelompoknya. Terlihat betina dewasa siamang yang sedang melakukan aktivitas grooming dengan individu remaja. Interkasi antara siamang dengan jenis kera lainnya ditunjukkan dari penggunaan areal yang sama oleh siamang, cecah dan monyet ekor panjang untuk mencari makan. 


\section{Keberadaan Satwa Lain di Areal Repong Damar Pahmungan}

Pada umumnya siamang toleran dengan satwa lain. Pada saat penelitian, terlihat siamang dan jenis primata lain menggunakan areal yang sama untuk mencari pakan namun tetap saling menjaga jarak. Hubungan sosial ini dimungkinkan, karena sumber pakan berlimpah. Namun demikian satwa-satwa ini tetap menjaga jarak satu sama lain agar tidak terjadi kontak langsung.

Menurut Bismark (1984), struktur hutan berpengaruh nyata terhadap satwa liar yang tinggal di dalamnya. Di dalam hutan banyak dijumpai berbagai jenis satwa yang hidup berdampingan, saling berinteraksi satu sama lain membentuk suatu rantai makanan yang tak terpisahkan. Suatu hutan tidak hanya dihuni oleh satu jenis satwa liar, tetapi juga memungkinkan terdiri dari beberapa jenis satwa yang hidup di dalamnya, baik sebagai tempat tinggal sementara, sebagai tempat bermigrasi, maupun sebagai tempat tinggal hidup dan berkembang biak. Jenis-jenis satwa lain yang dijumpai di areal Repong Damar, Pekon Pahmungan pada saat pengamatan (April 2015) yaitu: 5 spesies primata, 2 ordo Artiodactyla (Tabel 2).

Tabel 2. Jenis satwa lain yang ditemui di lokasi pengamatan pada bulan April 2015.

\begin{tabular}{clll}
\hline No. & Jenis & Nama latin & Lokasi \\
\hline 1. & Babi Hutan & Sus scrofa & 1 dan 2 \\
2. & Beruk & Macaca nemestrina & 1,2 , dan 3 \\
3. & Lutung kelabu & Presbytis cristata & 1 dan 3 \\
4. & Monyet ekor panjang & Macaca fascicularis & 1,2 , dan 3 \\
5. & Cecah & Presbytis melalophos & 1,2 , dan 3 \\
6. & Kukang & Nycticebus coucang & 2 dan 3 \\
7. & Kijang & Muntiacus muntjak & 1 \\
\hline
\end{tabular}

\section{E. Persepsi Masyarakat Terhadap Keberadaan Populasi Siamang di Repong Damar Pahmungan}

Persepsi masyarakat Pekon Pahmungan terhadap populasi siamang dapat dikatakan bahwa sebagian masyarakat paham bahwa siamang merupakan salah satu jenis primata yang dilindungi dan sebagian tidak memahami bahwa siamang primata yang dilindungi. Sebagian masyarakat yang kurang memahami menganggap bahwa kehadiaran siamang merupakan suatu gangguan bagi masyarakat. Masyarakat menjelaskan bahwa kehadiran siamang mengganggu tanaman masyarakat, karena siamang menjadikan tamaman masyarakat sebagai sumber pakan. Kondisi yang dikhawatirkan masyarakat adalah pada saat siamang memakan buah tanaman pada saat musim buah karena dapat merusak. Perburuan siamang yang di areal ini adalah salah satu cara masyarakat untuk mengurangi gangguan siamang terhadap kebun masyarakat. Perburuan sering dilakukan dengan penembakan menggunakan senapan. Namun untuk saat ini hal itu sudah mulai berkurang karena semakin banyaknya penelitian di areal tersebut dari berbagai instansi pendidikan yang secara tidak langsung memberikan wawasan dan pengetahuan tentang beberapa primata yang dilindungi di areal ini. Walaupun demikian, tetap tidak bisa terelakkan bahwa masih ada masyarakat yang melakukan perburuan terhadap satwa ini.

\section{KESIMPULAN}

Berdasarkan hasil penelitian dapat disimpulkan bahwa ukuran kelompok siamang di areal Repong Damar Pekon Pahmungan berjumlah 2-4 individu. Ukuran kelompok siamang yang terbesar dari seluruh pengamatan berjumlah 4 individu yang terdiri dari 1 individu 
jantan remaja, 1 individu jantan dewasa, 1 individu betina remaja, dan 1 individu betina dewasa. Proporsi perjumpaan tiap kategori dari hasil penelitian ini adalah 38,10\% remaja dan $61,90 \%$ dewasa. Berdasarkan jenis kelamin, perbandingan jantan dan betina (sex ratio) pada kategori siamang dewasa yaitu: (1:1) dan perbandingan jantan dan betina (sex ratio) pada kategori siamang remaja yaitu (1:1). Vegetasi di areal tersebut sangat beragam mulai dari pepohonan hingga tumbuhan bawah. Struktur dan komposisi vegetasi Repong Damar mendukung siamang melakukan aktivitas harian, tempat berlindung, dan tempat berkembangbiak.

\section{DAFTAR PUSTAKA}

Alikodra, H. S. 2002. Pengelolaan Satwa Liar, Jilid 1. Buku. Fakultas Kehutanan Institut Pertanian Bogor. Bogor. 357p.

- 2006. Populasi Primata Endemik Mentawai di Kompleks Hutan Desa Tiniti Siberut Utara. Laporan Penelitian. C.I. Jakarta. 159p.

2009. Biologi Konservasi Bekantan (Nasalis larvatus). Buku. Pusat Penelitian dan Pengembangan Hutan dan Konservasi Alam. Bogor. 354p

Bangun, T. M., S. S, Mansjoer., dan M. Bismark. 2009. Populasi dan Habitat Ungko (Hylobates agilis) di Taman Nasional Batang Gadis, Sumatera Utara. Jurnal Primatologi Indonesia.1:1410 5373.

CITES. Kategori Apendiks CITES. 1997. Diakses pada tanggal 20 Januari 2015. World Wide Web: http://en.wikipedia.org/cites.

Forum Komunikasi Kehutanan Masyarakat. 2002. Studi Kolaborasi: Pengelolaan Repong Damar Krui \pm Lampung Barat, Bandar Lampung. Syafa'at Advertising bekerjasama dengan Forum Komunikasi Kehutanan Masyarakat (FKKM).

Geissman, T. V., dan R. Nijman., dan Dallmann. 2006. The fate of diurnal primates in southern Sumatera. Hylobatidaes Journal. 2:18 z4.

Gittins, S. P., dan S. J. J. Raemakers. 1980. Siamang, lar, and agile hylobatidaes. [eds.]. malayan forest primates: Ten Years' Study in Tropical Rain Forest. 3:12 14.

Harianto, S. P. 1988. Habitat dan tingkah laku siamang (Hylobates syndactylus) di Calon Taman Nasional Way Kambas. Tesis. Fakultas Pascasarjana IPB. Bogor. Tidak dipublikasikan.

IUCN. 1994. IUCN Red List Categories. Fourtieth Meeting of the IUCN Council. Gland. Switzerland.

Iskandar, E. 2007. Habitat dan populasi owa jawa (Hylobates moloch) di Taman Nasional Gunung Halimun-Salak, Jawa Barat. Disertasi. Sekolah Pascasarjana, Institut Pertanian Bogor. Bogor.

McFarland, D. 1999. Animal Behavior, Psychobiology, Ethology and Evolution. Buku. Addison Wesley Longman Limited. England. 768p.

Nainggolan, V., dan B. S. Dewi, 2011. Analisis populasi jenis primata di Repong Damar Pekon Pahmungan Kecamatan Pesisir Tengan Kabupaten Lampung Barat. Skripsi. Fakultas Pertanian, Universitas Lampung. Lampung.

Presiden Republik Indonesia. 1999. Peraturan Pemerintah No. 7 Tahun 1999 Tentang: Pengawetan Jenis Tumbuhan dan Satwa. Kementrian Kehutanan. Jakarta.

Rinaldi, D. 1992. Penggunaan Metode Triangle dan Concentration Count dalam Penelitian Sebaran dan Populasi Hylobatidae (Hylobatidae). Media Konservasi.1:9 4.

Setya, P. 2012. Studi populasi dan perilaku harian lutung jawa di Situ Sangiang Resort Sangiang Taman Nasional Gunung Ceremai. Skripsi. Fakultas Pertanian, Universitas Lampung. Lampung. 
Supriatna, J., dan H. E. Wahyono. 2000. Panduan lapangan Primata Indonesia. Buku. Yayasan Obor Indonesia. Jakarta

Suyanto, A., M. H. Sinaga \& A. Saim. 2009. Mammals biodiversity in Tesso Nilo, Riau Province, Indonesia. Jurnal Zoo Indonesia. 2:79 88.

Tenaza, R. R. 1975. Territory and Monogamy Amongkloss Gibbons (Hylobates kloosii) in Siberut Island, Indonesia. Folia Primatologica. 24:60 80.

Tuti, H. 2012. Perjalanan multiabad Repong Damar: kajian aspek tata guna lahan. Seminar Nasional Agroforestri III. 23:3-4.

Whitten, A. J. 1980. The kloss gibon in Siberut Rain Forest. Disertation. Univ Cambridge. UK. 
Vol. 3 No. 3, September 2015 (85-94)

Halaman ini sengaja dikosongkan 